\title{
Lessons from the past: investigating historical data from bluefin tuna fisheries
}

\author{
Jean-Marc Fromentin ${ }^{1,}$ \\ ${ }^{1}$ Ifremer, Centre de Recherche Méditerranéen et Tropical, Avenue Jean Monnet, BP 171, 34203 Sète cedex, \\ France \\ *: Corresponding author: Jean-Marc Fromentin, Tel.: +33 4995732 32, Fax: +33 4995732 95, email address : \\ $\underline{\text { Jean.Marc.Fromentin@ifremer.fr }}$
}

\begin{abstract}
:
In 1963, the leading fisheries targeting Atlantic bluefin tuna (Thunnus thynnus) in the Norwegian Sea and North Sea suddenly collapsed without any warning. Little is known about this collapse and several hypotheses have been put forward, such as changes in migratory routes, recruitment failure or eradication of a sub-population: all of these hypotheses could result from natural causes and/or from overfishing. To help explain this mysterious event, an original data set of the main bluefin tuna fisheries of the 20th century, including total catch and size composition of the catch, has been compiled and analysed. The results reveal a strong and unambiguous link between the Nordic purse seine and Spanish trap fisheries during the 1950s and 1960s. However, this link vanished during the 1970s. In addition, the North-west Atlantic and Mediterranean trap fisheries appeared also to be partially connected to the Nordic fisheries. During the 1950s and 1960s, the main migration routes of bluefin tuna were probably from the Mediterranean spawning grounds and from the West Atlantic coasts to the Norwegian coast and North Sea, which were probably a key feeding ground at that time. The analyses also lead to the conclusion that interactions between environmental, trophic and fishing processes have probably affected bluefin tuna migration patterns which would have finally caused the Nordic fisheries collapse. This retrospective analysis finally leads to an original - albeit more speculative - hypothesis concerning Atlantic bluefin tuna population structure, therein conjectured as an assemblage of at least three sub-populations.
\end{abstract}

Keywords: Fisheries collapse $\cdot$ migration patterns $\cdot$ population structure $\cdot$ retrospective analysis $\bullet$ Thunnus thynnus 


\section{Introduction}

Atlantic bluefin tuna (Thunnus thynnus, Scombridae) is a top predator displaying a long life span and a low population growth rate which makes it more fragile to exploitation than tropical tunas (Fromentin and Fonteneau 2001). Bluefin tuna further exhibits a wide spatial distribution (the whole North Atlantic and adjacent seas) and a highly migratory behaviour (Mather et al. 1995; Fromentin and Powers 2005). However, its spatial dynamics are complex and partially unknown, in spite of recent progress made due to intensive electronic tagging experiments (e.g. Block et al. 2005; Sibert et al. 2006). Bluefin tuna is currently managed by the International Commission for the Conservation of Atlantic Tunas (ICCAT) under the hypothesis of two management units, although mixing between the two units is known to occur (ICCAT 2002). Both stocks are estimated to be strongly overfished and continue to be overexploited; the 2006 stock assessment points out a substantial risk of fisheries and population collapse (ICCAT 2007).

Since the first millennium before Christ, Mediterranean fishermen took benefits of the bluefin tuna seasonal migration, during which fish hug the coasts to join their spawning sites (Mather et al. 1995; Doumenge 1998). They traditionally used beach seines or hook and lines that were progressively replaced by a fixed gear --the trap-- which has been used all around the Mediterranean Sea and along the near Atlantic coasts since the $16^{\text {th }}$ Century. Along its millennium exploitation history, bluefin tuna fisheries did not remain stable but displayed conspicuous long-term fluctuations (Ravier and Fromentin 2001). However, the Nordic fisheries that took place in the Norwegian and North Sea between the 1930s and 1970s (Mather et al. 1995) give the most spectacular example of bluefin tuna fisheries collapse. During the 1950s, the Nordic fisheries were among the most productive ones, catching up to 18,000 tons/year, but they suddenly crashed down without any warning in 1963 . There were a few catches after this event, but at a much lower level. Also intriguingly, the mean size of the catch of these fisheries continuously increased, which may be interpreted in different ways, i.e. changes in the migratory routes, recruitment failure (due to natural causes and/or fishing), or eradication of a sub-population (Pusineri et al. 2002; Fromentin and Powers 2005).

This study aims to clarify this mysterious event because understanding such past event may substantially improve our knowledge on bluefin tuna population dynamics and ecology. To do so, an important data rescue from various sources has been carried out to compile a database including annual total catch and catch-at-size (i.e. the size composition of the catch) from the most important bluefin tuna fisheries of the $20^{\text {th }}$ century operating in the North Atlantic and Mediterranean Sea. This study presents an analysis of this original dataset. It supports the occurrence of significant spatial and temporal variations in bluefin tuna migratory behaviour and brings a novel hypothesis about the bluefin tuna population structure.

\section{Materials and Methods}

\section{The Nordic fisheries data}

The occurrence of large bluefin tuna $(>100 \mathrm{~kg})$ in the northern European waters is documented since the 1920s (Mather et al. 1995; MacKenzie and Myers 2007). Among the so-called 'Nordic' fisheries, the Norwegian purse seine fishery was the most important one (i.e. $~ 80 \%$ of the total catch of the Nordic fisheries) and operated in the North Sea and in the Norwegian Sea (offshore the Nordland and Troms provinces). A continuous time series of annual yields (in tons) from both areas has been built up from 1927 to 1982 from the archives of the Institute of Marine Research in Bergen (Norway), the official Norwegian catch statistics and the seven ICES reports of the bluefin tuna working group being published between 1964 and 1980 (Hamre and Tiews 1964; Hamre et al. 1966; 1968; 1971; Aloncle et 
al. 1974; 1977; 1981). This time series has been then updated until 2000 using the ICCAT database (www.iccat.int, Table 1). A time series of catch-at-size (CAS) from 1956 to 1979 and 1956 to 1969 (with a missing period from 1963 to 1966 due to the fishery collapse) have been collected from the ICES reports for the North Sea and the Norwegian Sea areas, respectively (Table 1). German and Danish fisheries (mostly handline, but also hook and line, purse seine and sport fishing) that operated in the North Sea, Skagerrak and Kattegat were less important than the Norwegian but not negligible. Time series of total yields (in tons) from these fisheries have been also built up from various sources, i.e. the above ICES reports and past scientific literature (Tiews 1963b; Pusineri et al. 2002). These time series ranged over 1947-1969 and 1938-1986 for Germany and Denmark, respectively (Table 1). CAS data were not available or very sporadic for Denmark, but a CAS time series could have been collected for Germany from 1951 to 1962 from the ICES reports and archives from the BFAFischerei Institute in Hamburg (Germany, J.P. Cornus Comm. pers.).

\section{The trap fisheries data}

Traps were the major and most productive bluefin tuna fisheries from the $16^{\text {th }}$ century until the advent of the Nordic fisheries (see Mather et al. 1995; Ravier and Fromentin 2001 and references herein). The most important trap fisheries operated along the coasts of Sicily, Sardinia, Tunisia in the Mediterranean Sea and Spain, Portugal and Morocco in the Northeast Atlantic (Ravier and Fromentin 2001). Using the historical material collected by these authors, continuous time series of annual catch (in number of fish) from 1900 to 2000 were collected, while time series of yields (in tons) from 1950 came from the ICCAT database (Table 1). CAS time series from 1950 to 1979 for the main Spanish trap Barbate could have been reconstructed from the above ICES reports and past scientific literature (i.e. Rodriguez-Roda 1960; 1964; 1966; 1967; 1970). CAS from the Spanish traps are available in the ICCAT database after 1979. However, these data were not included in the analyses because of their lack of consistency with the previous period.

CAS data were not available or sporadic for the Italian, Tunisian Portuguese and Moroccan traps in the ICES reports, ICCAT database or past literature. However, we could have rescued the full daily CAS information from the two major Sicilian traps, Favignana and Formica, between 1956 and 1990 from the archives of the Trapani fisheries service (G. Guarrasi Comm. pers.) which were representative from this fishery (Ravier and Fromentin 2001). This unique and highly valuable dataset includes 7031 CAS records that have been carefully checked and validated. Finally a CAS time from 1956 to 1984, including 6204 records, has been retained (the most recent years being deleted due to a strong decline in the catch and a too low sample size, Table 1).

Annual yields from 1930 to 2000 and a CAS time series from 1955 to 1961 of the Canadian and US traps have been gathered from the same ICES reports and ICCAT database. These traps were less productive than the Spanish or Italian ones. They are, however, of great interest because they were operating in the Northwest Atlantic, more precisely in Nova Scotia and Cape Cod, at the same time as the Nordic fisheries (Mather et al. 1995).

\section{Other fisheries data}

Besides the above major fisheries, there were a few important fisheries that appeared during the second half $20^{\text {th }}$ century, i.e. the French \& Spanish bait boat, the Japanese longline, the US purse seine and the Mediterranean (mostly French and Italian) purse seine.

The French \& Spanish bait boat resulted from the modernization during the mid-20th century of a handline fishery targeting North Atlantic albacore (Thunnus alalunga) and juveniles bluefin tuna in the Bay of Biscay since the mid-19 ${ }^{\text {th }}$ century (Bard 1981; Fromentin and Powers 2005). Continuous time series of annual yields (1940-2000) and CAS (1966-2000) have been built up from the ICCAT database and above ICES reports (Table 1). 
A purse seine fishery targeting juveniles bluefin tuna started in the 1930s but really arose during the early 1960s along the edge of the western Atlantic continental shelf, mostly between Cape Hatteras and the coasts of Maine (Mather et al. 1995). Continuous time series of annual yields (1958-2000) and CAS (1963-2000) have been also built up from the ICCAT database and above ICES reports (Table 1).

Longline also developed in the North Atlantic during the 1950s, primarily by Japan (Mather et al. 1995). The longliners primarily focused on medium-sized and large fish in temperate waters, with some extension in the equatorial area, such as the "Brazilian episode" between 1962 and 1967 (Fromentin and Powers 2005). These fisheries then expanded in the Mediterranean Sea and the Gulf of Mexico and are nowadays covering most of the bluefin tuna spatial distribution (ICCAT 2007). To take into account the spatial development of the Japanese fisheries and ICCAT database constraints, three different areas for this fishery were considered: the West Atlantic, the East Atlantic and the Mediterranean Sea (for more details about the areas, see ICCAT 2007). Continuous time series of annual yields for the West and East Atlantic ranged from 1957-2000, while this of the Mediterranean Sea from 1963-2000 (Table 1). Continuous CAS time series were available since 1971, 1970 and 1974 for the West, East Atlantic and Mediterranean, respectively (note that CAS data for the West Atlantic are also available in some years prior to 1971, i.e. 1957, 1965 and 1968).

Purse seine fisheries really took place in Mediterranean Sea after the Second World War, firstly in Yugoslavia (currently Croatia) and Italy, then in France during the 1960s. Following the development of the Japanese sushi-sashimi market during the 1980s, these fisheries considerably increased and new purse seine fisheries appeared, especially in Spain, Tunisia, Turkey and Libya, so that these fisheries are nowadays the most productive ones (Fromentin and Ravier 2005; ICCAT 2007). Continuous time series of annual yields have been built up from 1950, 1952, 1962 until 2000 for Croatia, Italy and France, respectively (Table 1, time series from Tunisia, Spain and Turkey purse seine were considered since they were less than 20 years long and started more than 15 years after the Nordic fisheries collapse). The CAS data has been compiled from the French fleet from 1968 to 2000 (but was missing in 1980). All data came from the ICCAT database.

\section{Data Analysis}

All the data (total catch or CAS) used for this study come from validated sources (e.g. ICES reports) or have been validated using cross-checks among different sources, inspection of the raw data and validation by different experts (see acknowledgements). Data that could not be validated were removed. All the time series were continuous, except the US and Canadian trap for which reported catches were missing in 1934, 1936 and 1941. As these missing values were clearly stated as unavailable (Hamre et al. 1966) and were not contiguous, they were estimated using the Eigen Vector Filtering method (e.g. Ibanez and Dauvin 1988), so that the final model retained more about $80 \%$ of the variance of the series.

In fine, the dataset included continuous time series which were of unequal lengths and which did not necessarily overlap over a long period (Table 1). To circumvent these difficulties, the time series that came from a homogeneous and/or similar geographical area (i.e. Mediterranean Sea, Northeast Atlantic and Northwest Atlantic) and gear type (i.e. trap, purse seine, longline and baitboat) were gathered (Table 1). The Mediterranean trap (MED-TP) thus includes the Italian and the Tunisian trap fisheries, the Mediterranean purse seine (MED-PS) includes the French, Italian and Yugoslavian purse seine, the Mediterranean longline (MED-LL) is the Japanese longline operating in that area, the Northeast Atlantic trap (NEA-TP) includes the Morrocan, Portuguese and Spanish traps, the Northeast Atlantic purse seine (NEA-PS) includes the Danish, German and Norwegian purse seine, the Northeast Atlantic longline (NEA-LL) is the Japanese longline operating in the North Atlantic East of the $45^{\circ} \mathrm{W}$ parallel, the Northeast Atlantic baitboat (NEA-BB) is the French and Spanish baitboat operating in the Bay of Biscay, the Northwest Atlantic trap (NWA-TP) includes the US and Canadian trap fisheries, the Northeast Atlantic purse seine (NWA-PS) is 
the US purse seine fleet while the Northeast Atlantic longline (NWA-LL) is the Japanese longline operating in the North Atlantic West of the $45^{\circ} \mathrm{W}$ parallel. Doing so, the number of time series has been reduced from 18 to 10,5 to 2 and 13 to 10 , for the yield, catch and CAS, respectively (Table 2). This grouping led to several advantages: (i) the number of time series per geographical and gear class is more balanced; (ii) each class of fisheries now displays one time series of yield and CAS and (iii) the period of overlap among time series is larger. Overall, this dataset allowed the numerical analyses to be more robust.

The decomposition of CAS data into Gaussian components that represent the different ageclasses is difficult for bluefin tuna, especially for fish older than 5 years, as the cohorts tend to become indistinguishable (Fromentin and Powers 2005). Furthermore, intensive fishing on juveniles tends to smooth over modal differences that might have originally existed. Therefore, the ageing procedure was performed as it is done by the ICCAT bluefin tuna working group, using the official ICCAT age-length key of each major geographical area to convert the CAS data into catch-at-age (CAA) data. The keys (i.e. von Bertalanffy equations, see ICCAT 1997) specify the probability that a fish of a given size belong to one of several age groups. The CAA data have been finally used to estimate the year-classes contribution to the catches (i.e. the proportion of each annual cohort in the catches) of each fishery.

In general, time series of catch and catch-per-unit-effort (CPUE) poorly reflect the underlying dynamics of fish populations because the former are directly affected by effort (with a few exceptions for some passive fisheries such as the traps, see Ravier and Fromentin 2001) and because both are impacted by gear catchability, changes in fishing strategy and technology as well as environmental variations (Hilborn and Walters 1992; Rouyer et al. 2008). However, the comparison of different sources of data, such as catch, yield, CAS and year-classes contribution, may help in detecting connectivity between fisheries, while reducing the risk of error due to a unique source of data.

To detect potential similarity and synchrony among the different fisheries, the time series of yields, CAS and CAA were analysed and compared using a step-by-step approach and applying standard methods, such as linear regression, principal component analysis (PCA) and cluster analysis (see e.g. Legendre and Legendre 1998). However, the above time series of yields were rarely stationary and both the mean and the variance varied over time (Figure 1). Non-stationarity is known to affect statistical analysis, especially hypothesis testing, and needs therefore to be corrected (Chatfield 1996; Pyper and Peterman 1998). To stabilize the variance (i.e. to make the variance homoscedastic) of the time series of yield, data were log-transformed prior to PCA and linear regression. To stabilize the mean, the most standard options are to removing time trend (estimated through filtering) or to prewithtening the time series (through e.g. first-order differencing). However, such procedure would lead to the removal of the major source of variance of these time series, which is mostly due to low frequencies (Figure 1). It would further prohibit the detection of slow changes and/or regime shifts. As the aim of the present study is to focus on long-term variability (and not short-term one), the log-transformed time series were not detrended or prewithtened, but the test procedures were adjusted to take account for serial autocorrelation, according to the method proposed by Pyper and Peterman (1998).

Bluefin tuna migrated in the North Sea and Norwegian Sea in summer to feed on herring and secondarily on mackerel (Tiews 1978). Therefore, changes in prey abundance or in environmental conditions in the Northeast Atlantic may have impacted bluefin tuna population dynamics (both in time and space). To investigate the potential impact of environmental and trophic factors on yields time series, the regime shift detection index (RSI) developed by Rodionov (2004; 2005) was therefore preferred to the General/Multivariate Linear Regression approach. The RSI is designed to detect statistically significant shifts in the mean level and the magnitude of fluctuations in time series, while handling outliers and autocorrelation, using a sequential t-test. The RSI was applied on historical time series of bluefin tuna catch, abundance of Norwegian Spring-spawning herring estimated from virtual population analysis (Toresen and Østved 2000) and in situ sea surface temperature (SST) provided by the Comprehensive Ocean-Atmosphere data set, COADS (http://www.cdc.noaa.gov/coads/). 
Only the results that are consistent among the different analyses (and so assumed to be robust) are finally discussed. All the analyses have been performed under Matlab 6.1 (Matlab 2006), but the RSI was performed using the Visual Basic application available at: http://www.beringclimate.noaa.gov/regimes/index.html.

\section{Results}

\section{Analyses of the yield data}

A correlation matrix between the 10 time series of yield has been computed on logtransformed data and then used to calculate a distance matrix, such as D = 1-R. As a quota was imposed to all the Western Atlantic fisheries in 1982, all the time series used to compute $\mathrm{R}$ and $\mathrm{D}$ have been truncated in 1982 to avoid any potential bias. A Principal Component Analysis and a cluster analysis have been then performed using $R$ and $D$, respectively. The dendrogram (i.e. tree diagram of the cluster) has been cut at $D=1$ (i.e. $R=0$ ) to determine the different groups. Two groups clearly emerged from the two analyses (Figure 2a,b). The first one included fisheries from different areas that were important during the 1950s and then strongly declined during the 1960s and 1970s (Figure 2b). The second group included two Northwest fisheries, i.e. the NWA-PS and NWA-LL that reached a peak during the 1960 s (i.e. during the so-called 'Brazilian episode', see 'Discussion') and then stabilized at lower levels as well as two Mediterranean fisheries (MED-PS and MED-LL) and one from the Northeast Atlantic (NEA-LL) which displayed a strong increase during the 1970s (Figure 2b). If this general classification was expected, more surprising was the inclusion of a Northwest fishery, i.e. the NWA-TP, into the group 1, i.e. together with the trap fisheries from the Mediterranean and Northeast Atlantic (MED-TP and NEA-TP) as well as the Nordic fisheries (NEA-PS).

\section{Analyses of the catch-at-size}

The buble plot of the catch-at-size (CAS) of the NEA-PS clearly displayed an increase in the mean size of the catch and a concomitant decrease in the dispersion of the size distribution during the 1960s and 1970s (i.e. after the collapse, Figure 3). Such pattern can be summarised by calculating the median and the inter-quartile-range (i.e. a robust measure of the variance that is equal to the difference between the 75th and 25th percentiles) of each annual size distribution and plotting them as a time series (Figure 4). The significant increase in the mean size and decrease in the dispersion of the CAS of the NEA-PS led to a significant negative relationship between both variables, i.e. higher the median size, lower the dispersion around the mean. A similar significant increase in the median size was also clearly detectable in the NEA-TP, but without significant decrease in the dispersion (Figure 4). The CAS of the MED-TP displayed a contrasting pattern with the two above fisheries since the median and the dispersion of the CAS were significantly positively related (i.e. higher the median size, higher the dispersion around the mean, Figure 4). Such pattern that is more usual in fisheries data was also detectable in the NWA-PS. The NWA-LL (as the other fisheries, i.e. the NEA-LL, NEA-BB, MED-LL and MED-PS) did not display any particular pattern.

Focusing on the four fisheries that displayed significant changes in the CAS, a potential link between variations in size and yield have been then investigated. For the three fisheries that targeted large fish, the median size was negatively related to the total yield, i.e. higher the yield, lower the median size of the fish (only the first two fisheries displayed a significant relationship after adjustment for serial autocorrelation, Figure 5). However, the dispersion of the CAS (which gives an indication of the number of different year-classes in the catches) was positively related to the NEA-PS yields and negatively to the MED-TP yields (Figure 5). This suggests that the years of lower yields in the NEA-PS were related to a few year- 
classes of large fish (i.e. $>240 \mathrm{~cm}$ ) while the years of higher yields were due to the occurrence of both medium- and large-size fish (i.e. $>180 \mathrm{~cm}$ ). In contrast, the years of lower yields in the MED-TP were related to larger fish but with a greater number of year-classes than the years of higher yields. This indicates that the underlying processes of collapse/decline of these two fisheries are likely to be different.

\section{Analyses of the year-classes contribution}

Comparing the CAS remains limited because of differences in catchability (i.e. some fisheries caught large/adult fish while others small/juvenile fish, Figure 6). Therefore, the year-classes contribution to the catches of each fishery have been also calculated and then compared. In average, there was a striking similarity between NEA-PS and NEA-TP which were both dominated by a few year-classes (or annual cohorts) from the late 1940s and early 1950s (Figure 6). The MED-TP displayed a different pattern. In this fishery, more year-classes have significantly contributed to the catches, as it was also the case for other fisheries (except the NWA-TP, figure not shown).

The principal component analysis (PCA) on the year-classes contribution to the catches of the NEA-PS gave useful details (Figure 7). Over the period 1956-1979, this fishery was dominated by about 10 continuous year-classes born between 1945 and 1953; the 1950 year-classes being the most dominant one. The other year-classes, especially after 1953, had little contribution to the whole variance. The PCA on the year-classes contribution to the yields of the NEA-TP displayed (once more) a similar picture (Figure 7). Here also, the yearclasses between 1945 and 1952 were largely dominant in the yields of the same period (i.e. 1956-1979), especially the year-classes 1949 and 1950. There was thus a kind of ebb and flow, i.e. the year-classes after 1950 progressively disappeared from these two Northeast Atlantic fisheries. There was no sudden stop in the arrival of new year-classes, neither a high dominance by a single year-class, as this has been suggested in the past. Note that the first important year-class that occurred in the NEA-PS (or NEA-TP) cannot be determined because the CAS only started in 1956 while the fishery developed during the 1930s-1940s. Information from the German fishery that went back to 1951 clearly indicated that the 1944 and 1945 year-classes were dominant in the catches of the early 1950s, so that the Nordic fisheries were probably supported by more than 10 year-classes.

As expected from Figure 6, the PCA on the MED-TP data (computed over the same period, i.e. 1956-1979) displayed a different pattern (Figure 7). If the same year-classes from 1945 to 1952 have significantly contributed to the catches (right part of the panel), even more important were the year-classes from 1958 to 1963, especially the year-class 1960, in the catch composition of this fishery (see left part of the panel). In other words, the MED-TP shared, in term of year-classes contribution, some similarities with the above Northeast Atlantic fisheries, but also some singularities.

It was also of interest to investigate the year-classes contribution to the catches of the NWATP, because this fishery also collapsed during the early 1960s (as the NEA-PS and NEA-TP, see Figures 1 and 2). However, the CAS was limited to a much shorter period than the above three fisheries (i.e. 1955-1961, Table 2) and the comparison must thus be interpreted with care. The yields of this fishery were mostly due to the contribution of the 1950-1953 yearclasses and poorly to the year-classes of the mid- and late 1950s, as it could have been expected from a fishery targeting small fish (Figure 7). The yields of the NWA-TP were thus dominated by the same year-classes as those of the NEA-PS and NEA-TP.

To extend the above comparison to a larger number of fisheries, two cluster analyses over more recent common periods were also performed. Over the period 1966-1979, the results were comparable to those from 1956-1979, i.e. the year-classes contribution to the catches of NEA-TP and NEA-PS were similar and were thus closely associated (Figure 8a). Over this period, the MED-TP was slightly apart but more closely linked to these two fisheries than NEA-BB and NWA-PS. Interestingly, the strong link between the NEA-TP and NEA-PS that emerged from all the above analyses seem to vanish during the 1970s. Indeed, the cluster 
tree performed on the 1971-1981 period showed that the year-classes contribution to the catches of NEA-TP was primarily associated with this of MED-TP (and then with NEA-LL) while the NEA-PS was spaced out (Figure 8b). This disruption may be understood at the light of Figure 4: while the strong ageing in the catches of the NEA-PS persisted until the late 1970s, it has been broken in the NEA-TP during the mid-1970s (as shown by the decrease in the median size since 1977). This indicates that the NEA-TP catches included new yearclasses since 1977 while those of the NEA-PS did not.

\section{Potential impact of environmental and trophic factors}

To investigate the potential impact of environmental and trophic factors on yields time series, the regime shift detection index (RSI) was calculated on the time series of NEA-PS, small herring (i.e. 0- and 1-year-old fish), fat herring (2- and 3-year-olds) and SST over the longest common period, i.e. 1927-1982. The aim is to detect statistically significant shifts in the mean level and thus to investigate potential synchrony between regime shifts of the different variables. As the time series of NEA-PS and herring displayed conspicuous serial autocorrelation, the RSI were calculated using the prewhitening procedure to adjust the significance level of detection of the shifts. The significance level was set at $10 \%$ and the time period at 10 years. Two regime shifts were detected for SST, firstly a cooling in 1962 (which also corresponds to the highest RSI value) and then another cooling in 1977 (Figure 9). Four regime shifts were detected for NEA-PS. The first two (in 1941 and 1949) corresponded to positive RSI and reflected the rising of the bluefin tuna fisheries in Norway, especially after the second World-War. The last two regime shifts occurred in 1963 (which is the second highest RSI value) and then in 1978, so in both cases one year after the two regime shifts detected in SST (Figure 9). Regime shifts in small and fat Norwegian Springspawning herring happened in 1954 and 1967 for both series and additionally in 1981 for small herring (Figure 9, the residuals were normally distributed for all the time series, although 2 and 3 outliers were detected in the small and fat herring, respectively).

\section{Discussion}

\section{Connectivity between fisheries}

The above analyses led to several consistent results of interest. First, most of the analyses displayed striking similarities between the Nordic fisheries (NEA-PS) and the Spanish traps (NEA-TP). The catch data indeed revealed a concomitant decline or collapse during the early 1960s. The CAS of both fisheries exhibited an ageing of the catch until the mid-1970s and a common dominant contribution of the year-classes 1945-1952. Therefore, the results advocated for a strong and a clear connection between these two fisheries leading to hypothesise (with a rather high level of confidence) that the largest part of fish caught in the North Sea and Norwegian Sea between July and October came from the Gibraltar strait and most probably from the Western Mediterranean where they were spawning in June. However, this connection was not unique or exclusive. The results also indicated possible and secondary connections between the Italian and US \& Canadian trap fisheries in the one hand and the Nordic fisheries in the other hand. The year-class at around 1950 contributed a lot to the catches of these two trap fisheries and the US \& Canadian trap further displayed a concomitant decline during the early 1960s. This could indicate that a non negligible part of the fish caught in the Norwegian Sea and North Sea in the past also came from the spawning grounds around Sicily and the Northeast American coasts. Such hypothesis is in agreement with Tiews (1963a) who estimated, on the basis of a few recaptures and mostly on the feeding condition of the fish, that about $12 \%$ of the catch of bluefin tuna in the Norwegian Sea and North Sea were of West Atlantic origin. It is also in agreement with Carlsson et al. (2006) who estimated from genetic analyses that the recent bluefin tuna 
fishery operating South of Iceland included fish migrating from different areas and recruited from different spawning grounds.

\section{Impact of herring stocks collapse and changes in oceanographic conditions}

So, main migration routes of Atlantic bluefin tuna during the 1950 s and 1960 s were probably from the Mediterranean spawning grounds and from the West Atlantic coasts to the Norwegian and North Sea, which were probably at that time a key feeding ground. Tiews (1978) estimated that bluefin tuna consumption in the Norwegian Sea and North Sea was substantial (up to 400000 tonnes in 1952) and that herring (mostly small herring) was the major prey (up to $75 \%$ ). Therefore, it is tempted to link the Nordic bluefin tuna fisheries collapse with the failures of the major herring stocks of the Northeast Atlantic in the late 1960 s and the early 1970s (Jakobsson 1985). However, this rather simplistic causal relationship is not in agreement with the RSI analysis, as the regime shifts for the Norwegian bluefin tuna and Norwegian Spring-spawning herring did not occur at the same periods. Furthermore, it does not help in understanding why bluefin tuna fisheries collapsed suddenly in 1963 while the decline of the various Northeast Atlantic herring stocks ranged over one or two decades.

The RSI analysis revealed that the two negative regime shifts in NEA-PS occurred in 1963 and 1978, so one year after the two regime shifts detected in SST over the 1927-1982 period. This may indicate that changes in temperature might have directly affected bluefin tuna migration behaviour, as this has been recently postulated (Ravier and Fromentin 2004; Sibert et al. 2006). It is finally worth noting that Japanese longliners caught 5,000 to 12,000 tonnes of bluefin tuna offshore Northern Brazil (i.e. in the equatorial Atlantic which is a typical fishing ground for tropical tuna but atypical for bluefin tuna) from 1962 to 1967, so just at the beginning of the cooling of the Northeast Atlantic and almost just after the Nordic fisheries collapse.

It is finally worth noting that Atlantic herring stocks displayed large temporal and spatial variations that appear to be partially due to climate changes (Corten 1990; Alheit and Hagen 1997; Corten 2001). The recruitment of the Norwegian Spring-spawning herring has been shown to be positively related to temperature (Torensen and Østved 2000). It could be thus conjectured that the cooling of the 1960s and 1970s has negatively affected Atlantic herring recruitment that has indeed significantly dropped in 1967. The subsequent crash of most of the Northeast Atlantic herring, that took place a few years later, might be due to the persistence of a too high fishing capacity (not anymore sustainable) which induced a huge increase in the fishing mortality during the 1960s, as shown by Torensen and Østved (2000) and Serchuk et al. (1996). This episode could thus be seen as another interesting example of synergistic interactions between environmental changes and exploitation (see Planque et al. 2008). So, if the lack of prey is probably not the main cause of the Nordic bluefin tuna fisheries collapse in 1963, it could have affected bluefin tuna population dynamics later, i.e., during the late 1960s and the 1970s.

\section{Changes in migration patterns versus recruitment failure}

Confronting present results with literature, it is thus tempting to relate the Nordic fisheries collapse to changes in bluefin tuna migration patterns which might have resulted from the rapid cooling of the Northeast Atlantic and, secondarily, from the decline/collapse of the Northeast Atlantic herring stocks. However, this hypothesis can hardly explain why the strong connection between the Nordic fisheries and the Spanish traps have lasted so long and did not vanish before the mid-1970s. This result that appears to be robust in the above analyses could advocate for another hypothesis, i.e. bluefin tuna recruitment failure (in relation to herring stocks collapse, cooling and/or overfishing). Yields from the French and Spanish bait boat fisheries, which were the major fisheries targeting juveniles bluefin tuna in the Northeast 
Atlantic during the 1950 s and 1960 s, displayed no significant decline, but high year-to-year variations (Figure 1). Such large fluctuations are also the major feature of the standardized CPUE time series which started in 1975 (Figure 10). However, the historical nominal CPUE, which are available from 1952 to 1975, tend to display a decline during the 1950s and a subsequent increase during the late 1960s and early 1970s. The early 1960s was thus a period of lower catch rates of juveniles bluefin tuna. Furthermore, a recent study showed that the fishing mortality rates on bluefin tuna were significant in the North Sea and Norwegian Sea during the period 1956-1979 (albeit much lower than currently) and that overfishing may have occurred during the 1950s (Fromentin and Restrepo 2009). The above information remains too scarce to strongly conclude for recruitment overfishing but this hypothesis cannot be rejected and would deserve deeper investigation. Although these results gave little support to the hypothesis of the eradication of a sub-population, they indicate that fishing had probably affected bluefin tuna population dynamics during the 1950s. Note that the mean condition factor K of bluefin tuna in the North Sea did not change significantly between 1952 and 1974, indicating that bluefin tuna recruitment has probably not been affected by the condition of the spawners.

The causes of the Nordic fisheries collapse are thus likely to result from interactions between environmental, trophic and fishing processes which may have finally impacted bluefin tuna migration patterns (and possibly recruitment during a decade). The fact that the Spanish traps also displayed a lack of new year-classes from the mid-1950s until the mid-1970s might be due to the stay of bluefin tuna in the Northwest Atlantic, as the high catches offshore Brazil and along the Northeast coasts of America during the 1960s could advocate for it. This hypothesis is obviously more conjectural, but Tiews (1963a) already put forward that the immigrating bluefin tuna from the West Atlantic into the North Sea during the 1950s might have stay in the East Atlantic the following years. Such behaviour has been recently observed (over three years) through electronic tagging experiments (Block et al. 2005). Electronic tagging also revealed that the Northwest Atlantic (especially the area being delimited by the Gulf of Maine, Newfoundland and the Gulf Stream) has become a key feeding ground for bluefin tuna of both Western and Eastern origins during the 1990s and early 2000s (Block et al. 2001; Block et al. 2005; Royer et al. 2008). So, the present analysis of historical data together with the most recent findings tends to show that the main feeding grounds of bluefin tuna have probably drastically changed during the half past $20^{\text {th }}$ century, shifting, at least one time, from the East to the West side of the North-Atlantic. Consequently, changes in bluefin tuna migratory routes might be also seen as a response/adaptation of the fish to shifts in oceanographic conditions and prey availability.

\section{Consideration on population structure}

The decline of the trap fisheries during the second half century is traditionally attributed to the expansion of the purse seine fisheries in the Mediterranean (which also target large bluefin tuna during the spawning period) and coastal pollution (e.g. Doumenge 1998; Addis et al. 2008). These factors may have surely played a role but the present study showed that other processes, such as changes in migrations, probably also took place. However, the strong differences between the Spanish traps (NEA-TP) and the Mediterranean ones (MED-TP) can hardly be explained by changes in migration. The years of low catch in both trap fisheries were related to larger fish, but to a larger number of year-classes in the unique case of the Mediterranean fisheries. Importantly, the catch of the Mediterranean traps did not display any significant ageing and did not crash during the early 1960s but a decade later (the 1958-1963 year-classes supplied rather high catches to this fishery until the late 1960s). The century long time series of these two fisheries (in number of fish, Figure 1) displayed different patterns. The Mediterranean traps that exhibited conspicuous pseudo-periodic fluctuations of 100-120 years (Ravier and Fromentin 2001) actually dropped during the 1920 s and remained at a rather constant medium/low level until the 1970s. In contrast, the Northeast Atlantic trap slightly increased from 1900 until the late 1950s and then suddenly collapse during the early 
1960s, as the Nordic fisheries (note however that the two trap time series are not in opposition or significantly negatively correlated). All these features indicate that the underlying processes of collapse/decline of these two fisheries are likely to be different. This was unexpected as the literature assumed that bluefin tuna come from the North Atlantic to spawn in the Mediterranean Sea and then go back (Mather et al. 1995; Fromentin and Powers 2005).

Collecting the above dissimilarities with (i) the evidence of a new spawning ground in the Eastern Mediterranean Sea (Karakulak et al. 2004) and (ii) significant genetic differences (from both microsatellite and mitochondrial markers) between the Western and Eastern Mediterranean in the one hand and the Gulf of Mexico and the Mediterranean in the other hand (Carlsson et al. 2004; 2007), it may be hypothesised that Atlantic bluefin tuna is constituted by at least 3 sub-populations: (1) a highly migratory one over all the North Atlantic (which would spawn in the Western and Central Mediterranean), (2) a more resident one in the Mediterranean (spawning in the Central and Eastern Mediterranean) and (3) a more resident one in the West Atlantic (spawning in the Gulf of Mexico). During the 1950-1960s, the sub-population (1) would have been dominant and would have spatially mixed to some extent with the 2 others. This sub-population would have been highly exploited during the 1950 s and 1960s by the Northeast and Northwest fisheries. The declining catch in the North Atlantic and the increasing catch in the Mediterranean since the early 1980s may thus be interpreted as a change in sub-population size in response to environmental changes (in a analogous way as the sockeye salmon, see Hilborn et al. 2003) and overexploitation (firstly on sub-population 1 and then on sub-population 3). Since the 1980s, the sub-population (2) would have become dominant while sub-populations (1) and (3) would have remained at low levels. Current overexploitation (especially in the Western Mediterranean Sea which was the fishing hotspot of the 1980s and 1990s) might explain why only a small number of fish came back in the Northeast Atlantic (South of Iceland) since the last warming of the Northeast Atlantic (Figure 9).

Very large bluefin tuna ( $>700 \mathrm{~kg}$ ) almost disappeared from the traditional Western Mediterranean and Northeast Atlantic fishing grounds, but were present offshore the Libyan coasts (Central Mediterranean) when this fishing ground started to be exploited in the early 2000s. Such an interesting observation may reflect the occurrence of cryptic biomass and may also advocate for complex population structure. However, this hypothesis of 3 subpopulations remains highly speculative and probably simplistic. There are indeed plausible interplays between population structure and spatial dynamics as well as interactions between sub-populations (especially in a case of a metapopulation, Kritzer and Sale 2004; Fromentin and Powers 2005). Whatever, recent studies clearly indicate that Atlantic bluefin tuna population structure is probably more complex than currently suspected (see e.g. Carlsson et al. 2004; 2006).

\section{Perspectives}

These results thus suggest that Atlantic bluefin tuna might have been overexploited since the 1950s or 1960s in some regions (such as the North Sea or the Northwest Atlantic), but less in other areas (such as the Central and Eastern Mediterranean). This feature might explain why bluefin tuna could have sustained the tremendous increase in fishing effort in the Mediterranean Sea since the 1980s. However, the situation is nowadays drastically different because bluefin tuna is heavily exploited over its whole spatial distribution for a decade (Fromentin and Powers 2005; ICCAT 2007). There is thus no more refuge and all the potential sub-populations are currently exploited. This new situation is likely to strongly reduce bluefin tuna resilience. This issue has thus important impacts for management and conservation. In a context of heavy overexploitation and overfishing, it is crucial to better understand bluefin tuna population structure and spatial dynamics and their interactions with fishing and environmental conditions. This could be investigated through an integrated and ambitious research project that would apply traditional (e.g. histological analyses, larval 
survey) and advanced (e.g. genetic and biochemical markers, electronic tag) techniques on a substantial number of fish sampled over the whole spatial distribution of the species. Such an ambitious project would be obviously costly, although it would only correspond to a small percent of the annual benefits of the valuable bluefin tuna fisheries and farming.

\section{Acknowledgement}

All my gratitude to J. Hamre, K. Tiews, J. Rodriguez-Roda and $\mathrm{H}$. Aloncle for their pioneering work in collecting consistent catch statistics of high quality from the Norwegian, German, Spanish and French bluefin tuna fisheries (currently available in the different ICES reports). I also warmly thank G. Guarrasi who provided the highly valuable catch-at-size dataset from Favignana and Formica trap fisheries, S. Myklevoll and J.P. Cornus for some important information and complementary data on the Norwegian and German fisheries and R. Toresen, for the data on the Norwegian Spring-spawning Herring. I am also very grateful to A. Fonteneau who is an untiring chaser of historical fisheries data who gave me precious information and to L. Nøttestad, M. Tangen and $\varnothing$. Tangen for constructive and passionate discussion on the Norwegian bluefin tuna and herring fisheries.

\section{References}

Addis, P., Dean, J.M., Pesci, P. et al. (2008) Effects of local scale perturbations in the Atlantic bluefin tuna (Thunnus thynnus L.) trap fishery of Sardinia (W. Mediterranean). Fisheries Research 92, 242-254.

Alheit, J., Hagen, E. (1997) Long-term climate forcing of European herring and sardine populations. Fisheries Oceanography 6, 130-139.

Aloncle, H., Bakken, E., Rodriguez-Roda, J., Tiews, K. (1981) Seventh report of the bluefin tuna working group. ICES Cooperative Research report Serie A, 100, 70pp.

Aloncle, H., Hamre, J., Rodriguez-Roda, J., Tiews, K. (1974) Fifth report of the bluefin tuna working group. ICES Cooperative Research report Serie A, 40, 52pp.

Aloncle, H., Hamre, J., Rodriguez-Roda, J., Tiews, K. (1977) Sixth report of the bluefin tuna working group. ICES Cooperative Research report Serie A, 71, 49pp.

Bard, F.X. (1981) Le thon germon Thunnus alalunga (Bonaterre 1788) de l'océan atlantique. Thèse de Doctorat d'Etat, Université Pierre et Marie Curie, Paris 6, $330 \mathrm{pp}$.

Block, B.A., Dewar, H., Blackwell, S.B., et al. (2001) Migratory Movements, Depth Preferences, and Thermal Biology of Atlantic Bluefin Tuna. Science 293, 1310-1314.

Block, B.A., Teo, S.L.H., Walli, A., et al. (2005) Electronic tagging and population structure of Atlantic bluefin tuna. Nature 434, 1121-1127.

Carlsson, J., McDowell, J.R., Carlsson, J.E.L., Graves, J.E. (2007) Genetic Identity of YOY Bluefin Tuna from the Eastern and Western Atlantic Spawning Areas. Journal of Heredity 98, 23-28.

Carlsson, J., McDowell, J.R., Carlsson, J.E.L., Olafsdottir, D., Graves, J.E. (2006) Genetic heterogeneity of Atlantic bluefin tuna caught in the eastern North Atlantic Ocean south of Iceland. ICES Journal of Marine Science 63, 1111-1117.

Carlsson, J., McDowell, J.R., Diaz-Jaimes, P., et al. (2004) Microsatellite and mitochondrial DNA analyses of Atlantic bluefin tuna (Thunnus thynnus thynnus) population structure in the Mediterranean Sea. Molecular Ecology 13, 3345-3356.

Chatfield, C. (1996) The analysis of times series: an introduction $4^{\text {th }}$ Edition, Chapman \& Hall, London $283 \mathrm{pp}$.

Corten, A. (1990) Long-term trends in pelagic fish stocks of the North Sea and adjacent waters and their possible connection to hydrographic changes. Netherlands Journal of Sea Research 25, 227-235. 
Corten, A. (2001) Northern distribution of the North Sea herring as a response to high water temperatures and/or low food abundance. Fisheries Research 50, 189-204.

Doumenge, F. (1998) L'histoire des pêches thonières. Collective Volume of Scientific Papers ICCAT 50, 753-803.

Fromentin, J.-M., Fonteneau, A. (2001) Fishing effects and life history traits: a case-study comparing tropical versus temperate tunas. Fisheries Research 53, 133-150.

Fromentin, J.-M., Powers, J.E. (2005) Atlantic bluefin tuna: population dynamics, ecology, fisheries and management. Fish and Fisheries 6, 281-306.

Fromentin, J.-M., Ravier, C. (2005) The East Atlantic and Mediterranean bluefin tuna stock: looking for sustainability in a context of large uncertainties and strong political pressures. Bulletin of Marine Science 76, 353-362.

Fromentin, J.-M., Restrepo, V. (2009) A year-class curve analysis to estimate mortality of Atlantic bluefin tuna caught by the Norwegian fishery from 1956 to 1979. Collective Volume of Scientific Papers ICCAT 62, in press.

Hamre, J., Lozano, F., Rodriguez-Roda, J., Tiews, K. (1966) ICES report from the bluefin tuna working group. ICES Statistical News letters 26, 34pp.

Hamre, J., Lozano, F., Rodriguez-Roda, J., Tiews, K. (1968) ICES report from the bluefin tuna working group. ICES Statistical News letters 38, 27pp.

Hamre, J., Maurin, C., Rodriguez-Roda, J., Tiews, K. (1971) Fourth ICES report of the bluefin tuna working group. ICES Cooperative Research report Serie A, 23, 49pp.

Hamre, J., Tiews, K. (1964) ICES Report from the bluefin tuna working group. ICES Statistical News letters 20, 43pp.

Hilborn, R., Quinn, T.P., Schindler, D.E., Rogers, D.E. (2003) Biocomplexity and fisheries sustainability. Proceedings of the National Academy of Science US 100, 6564-6568.

Hilborn, R., Walters, C.J. (1992) Quantitative fisheries stock assessment. Choice, dynamics and uncertainty, Vol., Chapman \& Hall, New-York.

Ibanez, F., Dauvin, J.C. (1988) Long-term changes (1977-1987) in a muddy fine sand Abra alba - Melinna palmata community from the Western English Channel: multivariate timeseries analysis. Marine Ecology Progress Series 49, 65-81.

ICCAT (1997) 1996 SCRS detailed report on bluefin tuna. Collective Volume of Scientific Papers ICCAT 46, 1-301.

ICCAT (2002) ICCAT workshop on bluefin tuna mixing. Collective Volume of Scientific Papers ICCAT 54, 261-352.

ICCAT (2007) Report of the 2006 Atlantic Bluefin Tuna Stock Assessment Session. Collective Volume of Scientific Papers ICCAT 60, 652-880.

Jakobsson, J. (1985) Monitoring and Management of the Northeast Atlantic Herring Stocks. Canadian Journal of Fisheries and Aquatic Science 42, s207-s221.

Karakulak, S., Oray, I., Corriero, A., et al. (2004) Evidence of a spawning area for the bluefin tuna (Thunnus thynnus L.) in the eastern Mediterranean. Journal of Applied Ichthyology 20, 318-320.

Kritzer, J.P., Sale, P.F. (2004) Metapopulation ecology in the sea: from Levins' model to marine ecology and fisheries science. Fish and Fisheries 5, 131-140.

Legendre, P., Legendre, L. (1998) Numerical ecology $2^{\text {nd }}$ Edition, Elsevier, Amsterdam, 853 pp.

MacKenzie, B.R., Myers, R.A. (2007) The development of the northern European fishery for north Atlantic bluefin tuna Thunnus thynnus during 1900-1950. Fisheries Research 87, 229239.

Mather, F.J., Mason Jr, J.M., Jones, A. (1995) Historical document: life history and fisheries of Atlantic bluefin tuna. NOAA Technical Memorandum NMFS-SEFSC 370, 165 pp.

Matlab (2006) Matlab R2006a, The language of technical computing MathWorks Inc., Natick, MA, USA.

Planque, B., Fromentin, J.M., Cury, P.M., et al. (2008) How does fishing alter marine populations and ecosystems sensitivity to climate? Progress In Oceanography in press.

Pusineri, C., Ravier, C., Fromentin, J.-M. (2002) Retrospective analysis of the bluefin tuna Nordic fisheries data. Collective Volume of Scientific Papers ICCAT 54, 517-526. 
Pyper, B.J., Peterman, R.M. (1998) Comparison of methods to account for autocorrelation in correlation analyses of fish data. Canadian Journal of Fisheries and Aquatic Science 55, 2127-2140.

Ravier, C., Fromentin, J.-M. (2001) Long-term fluctuations in the Eastern Atlantic and Mediterranean bluefin tuna population. ICES Journal of Marine Science 58, 1299-1317.

Ravier, C., Fromentin, J.-M. (2004) Are the long-term fluctuations in Atlantic bluefin tuna (Thunnus thynnus) population related to environmental changes? Fisheries Oceanography 13, 145-160.a

Rodionov, S. (2004) A sequential algorithm for testing climate regime shifts. Geophysical Research Letters 31, L09204.

Rodionov, S., Overland, J.E. (2005) Application of a sequential regime shift detection method to the Bering Sea ecosystem. ICES J. Mar. Sci. 62, 328-332.

Rodriguez-Roda, J. (1960) Consideraciones sobre la biología del atún, Thunnus thynnus (L.), de Barate (costa subatlántica de España). Boletin de la Real Siciadad Española de Historia Natural, Madrid 58, 347-362.

Rodriguez-Roda, J. (1964) Biologia del Atun, Thunnus thynnus (L.), de la costa sudatlantica de Espana. Investigacion Pesqua 25, 33-146.

Rodriguez-Roda, J. (1966) El atun, Thunnus thynnus (L.), de la costa sudatlantica de España en la campaña almadrabera del año 1964 y consideraciones sobre las fluctuaciones periodicas. Investigacion pesquera 30, 9-35.

Rodriguez-Roda, J. (1967) Fecundidad del atun, Thunnus thynnus (L.), de la costa sudatlantica de España. Investigacion pesquera 31, 35-52.

Rodriguez-Roda, J. (1970) El atún, Thunnus thynnus (L.), del sur de España en la campaña almadrabera del año 1969 y su relacíon con la temperatura y transparencia del agua del mar. Investigacion pesquera, Consejo Superior de Investigaciones Científicas, Barcelona 34, 503-514.

Rouyer, T., Fromentin, J.M., Ménard, F., et al. (2008) Complex interplays between population dynamics, environmental forcing and exploitation in fisheries. Proceedings of the National Academy of Sciences US 105, 5420-5425.

Royer, F., Wilson, S., Lutcavage, M. (2008) Spatial dynamics of Atlantic bluefin tuna in the North-Western Atlantic: Seasonal distribution, depth behavior and effect of the Gulf Stream variability. Marine Ecology Progress Series In press.

Serchuk, F.M., Kirkegaard, E., Daan, N. (1996) Status and trends of the major roundfish, flatfish, and pelagic fish stocks in the North Sea: thirty-year overview. ICES Journal of Marine Science 53, 1130-1145.

Sibert, J.R., Lutcavage, M.E., Nielsen, A., Brill, R.W., Wilson, S.G. (2006) Interannual variation in large-scale movement of Atlantic bluefin tuna (Thunnus thynnus) determined from pop-up satellite archival tags. Canadian Journal of Fisheries and Aquatic Science 63, 2154-2166.

Tiews, K. (1963a) An attempt to estimate the rate of transatlantic exchange of large bluefin tuna from German tuna catches by means of the feeding condition factor K. ICES Scombriform Fish Committee 9, 59-67.

Tiews, K. (1963b) Der Thunbestand (Thunnus thynnus [linnaeus]) in der Nordsee, seine Wanderungen, seine transatlantischen Beziehungen und seine Nutzung durch die deutsche Fischerei (article in German, summary in English). Archiv für Fischereiwissenschaft 14, 105168.

Tiews, K. (1978) On the disappearance of bluefin tuna in the North Sea and its ecological implications for herring and mackerel. Rapport et Procès-verbaux des Réunions du Conseil international de l'Exploration de la Mer 172, 301-309.

Toresen, R., Østved, J. (2000) Variation in abundance of Norwegian spring-spawning herring (Clupea harengus, Clupeidae) throughtout the 20th century and the influence of climatic variations. Fish and Fisheries 1, 231-256. 
Tables

Table 1

\begin{tabular}{|c|c|c|c|c|c|c|}
\hline FISHERIES & Catch (numbers) & Yield (tons) & CAS & Main Fishing Area & Geographical Class & Gear Class \\
\hline Portuguese Trap & $1900-1933$ & 1950-1969 & - & Southern Portugal & Northeast Atlantic & Trap \\
\hline Spanish Trap & $1900-2000$ & $1950-2000$ & $1956-1982$ & Southern Spain & Northeast Atlantic & Trap \\
\hline Morrocan Trap & $1927-1962$ & $1950-2000$ & - & Western Morrocco & Northeast Atlantic & Trap \\
\hline Tunisian Trap & $1900-2000$ & $1950-2000$ & - & Northern Tunisia & Mediterranean & Trap \\
\hline Italian Trap & $1900-2000$ & $1950-2000$ & $1956-1984$ & Sicily, Sardinia & Mediterranean & Trap \\
\hline Canadian \& US Trap & - & $1930-2000$ & $1955-1961$ & Cape Cod to Nova-Scotia & Northwest Atlantic & Trap \\
\hline Norwegian Purse Seine & - & $1927-2000$ & $1956-1979$ & North Sea & Northeast Atlantic & Purse seine \\
\hline Norwegian Purse Seine & - & 1950-1969 & 1956-1969 & Norwegian Sea (North of $62^{\circ} \mathrm{N}$ ) & Northeast Atlantic & Purse seine \\
\hline German handline \& purse seine & - & $1947-1969$ & 1951-1962 & North Sea & Northeast Atlantic & Purse seine \\
\hline Danish handline \& purse seine & - & $1938-1986$ & - & North Sea, Skagerrak, Kattegat & Northeast Atlantic & Purse seine \\
\hline Yugoslvia/Croatia Purse Seine & - & $1950-2000$ & - & Adriatic Sea & Mediterranean & Purse seine \\
\hline Italian Purse Seine & - & $1952-2000$ & $1971-2000$ & Western and Central Mediterranean & Mediterranean & Purse seine \\
\hline French Purse Seine & - & $1962-2000$ & $1968-2000$ & Northwestern Mediterranean & Mediterranean & Purse seine \\
\hline US Purse Seine & - & $1958-2000$ & $1963-2000$ & Cape Hatteras to Gulf of Maine & Northwest Atlantic & Purse seine \\
\hline French \& Spanish Bait Boat & - & $1940-2000$ & $1966-2000$ & Bay of Biscay & Northeast Atlantic & Baitboat \\
\hline Japanese Longline & - & $1957-2000$ & $1971-2000$ & Northwest Atlantic & Northwest Atlantic & Longline \\
\hline Japanese Longline & - & $1957-2000$ & $1970-2000$ & Northeast Atlantic & Northeast Atlantic & Longline \\
\hline Japanese Longline & - & $1963-2000$ & $1974-2000$ & Western and Central Mediterranean & Mediterranean & Longline \\
\hline
\end{tabular}

Table 1 List of the bluefin tuna fisheries of the $20^{\text {th }}$ century for which continuous time series of catch, yield and catch-at-size have been collected. Information about the range of the time series, location of the fisheries, geographical and gear class is given. 
Table 2

\begin{tabular}{|l|c|c|c|c|}
\hline FISHERIES & Acronym & Catch (numbers) & Yield (tons) & CAS \\
\hline Mediterranean Trap & MED-TP & $1900-2000$ & $1950-2000$ & $1956-1984$ \\
\hline Mediterranean Purse Seine & MED-PS & - & $1950-2000$ & $1968-2000$ \\
\hline Mediterranean Longline & MED-LL & - & $1963-2000$ & $1974-2000$ \\
\hline Northeast Atlantic Trap & NEA-TP & $1900-2000$ & $1950-2000$ & $1956-1979$ \\
\hline Northeast Atlantic Purse Seine & NEA-PS & - & $1927-2000$ & $1951-1979$ \\
\hline Northeast Atlantic Longline & NEA-LL & - & $1957-2000$ & $1970-2000$ \\
\hline Northeast Atlantic Baitboat & NEA-BB & - & $1940-2000$ & $1966-2000$ \\
\hline Northwest Atlantic Trap & NWA-TP & - & $1930-2000$ & $1955-1961$ \\
\hline Northwest Atlantic Purse Seine & NWA-PS & - & $1958-2000$ & $1963-2000$ \\
\hline Northwest Atlantic Longline & NWA-LL & - & $1957-2000$ & $1971-2000$ \\
\hline
\end{tabular}

Table 2 List of time series of catch, yield and catch-at-size that have been used for the analyses. This list came from a grouping of the time series listed in table 1, according to their geographical area and gear class (see text). Acronyms used in the text and ranges of the time series are given. 


\section{Figures}

Figure 1 Plot of the 2 time series of catch (in number of fish) and 10 time series of yield (raw data in tons) from 1900 to 2000 that have been kept for the analyses. Acronyms are given in table 2 .

Figure 2 (a) Tree diagram of the cluster (dendrogram) performed on the distance matrix calculated over the 10 time series of yields (log-transformed) from 1950 to 1981. (b) Plot of the first three axes of the Principal Component Analysis (PCA) performed on the correlation matrix calculated over the same 10 time series of yield. The percentage of variance explained by each axis is given in parenthesis and the grouping from the cluster analysis is superimposed. The time series of the 2 groups that are identified by the cluster analysis and the PCA are displayed. Acronyms are given in table 2.

Figure 3 Bubbleplot of the catch-at-size of the Northeast Atlantic purse seine fishery (NEAPS). x-axis: time (year); y-axis: fork length $(\mathrm{cm})$. Data are in frequency and the size of the bubble is proportional to the value.

Figure 4 left panel Plots of median size $(\mathrm{cm})$ of the catch-at-size of 5 selected fisheries. $\mathrm{x}$ axis: time (year); y-axis: length (cm). Medium panel Plots of the inter-quartile-range (a robust measure of the variance) of the catch-at-size of the same fisheries (same axes). Right panel Scatterplots of the median size versus the inter-quartile range. A linear regression is superimposed on each plot together the probability value when significant after adjustment for serial autocorrelation, according to the method proposed by Pyper and Peterman (1998). Acronyms are given in table 2.

Figure 5 left panel Scatterplots of the annual yields (log-transformed) versus the annual median size of the four fisheries that displayed significant changes in their catch-at-size. Right panel Scatterplots of the annual catch (ton) versus the annual inter-quartile-range $(\mathrm{cm})$ of the same four fisheries. A linear regression is superimposed on each plot together the probability value when significant after adjustment for serial autocorrelation, according to the method proposed by Pyper and Peterman (1998). Acronyms are given in table 2.

Figure 6 left panel plots of mean catch-at-size over the whole time series of six selected fisheries. x-axis: length (cm); y-axis: frequency (\%). Right panel plots of the year-classes (i.e. annual cohorts) contribution to the caches for the same six fisheries. $x$-axis: time (year); $\mathrm{y}$-axis: frequency (\%). Acronyms are given in table 2 .

Figure 7 top-left Plot of the first two axes of the Principal Component Analysis performed on the covariance matrix between the year-classes contribution to the caches of the Northeast Atlantic purse seine (NEA-PS) between 1956 and 1979. Bottom-left Same analysis and same period for the Northeast Atlantic trap (NEA-TP). Top-right Same analysis and same period for the Mediterranean trap (MED-TP). Bottom-right Same analysis but over the 19561961 period for the Northwest Atlantic trap (NWA-TP).

Figure 8 (a) Tree diagram of the cluster (dendrogram) performed on the distance matrix between the total year-classes contribution to the caches of 5 fisheries for which time series are available from 1966 to 1979. (b) Same for the 7 fisheries for which time series are available from 1971 to 1981 (MED-PS was not included because of missing CAS in 1980). Acronyms are given in table 2 .

Figure 9 top-left Plot of the regime shift detection in the sea surface anomalies (SST) of the Northeast Atlantic from 1927 to 1982 . The bold line represents the mean for each regime while the lower panel display the regime shift index corresponding to each significant regime 
shift (see text and Rodionov 2004; 2005). Top-right Same for the time series of the Northeast Atlantic purse seine (NEA-PS). Bottom-left Same for the time series of small herring. Bottom-right Same for the time series of fat herring.

Figure 10 Historical nominal CPUE from 1952 to 1975 of the French and Spanish bait boat fisheries operating in the Bay of Biscay together with the current standardized CPUE of the Spanish bait boat fisheries from 1975 to 2007 (source ICCAT). 

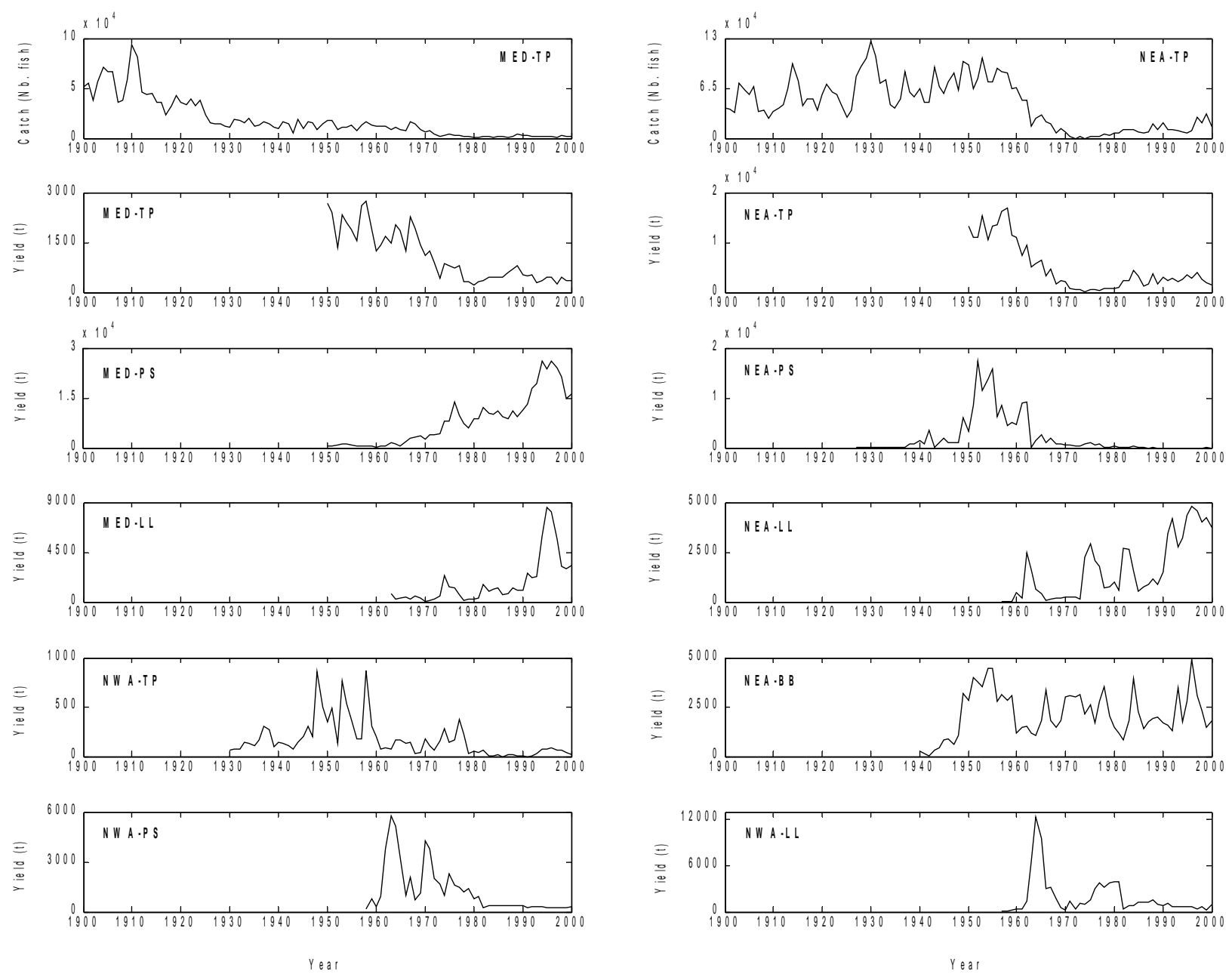


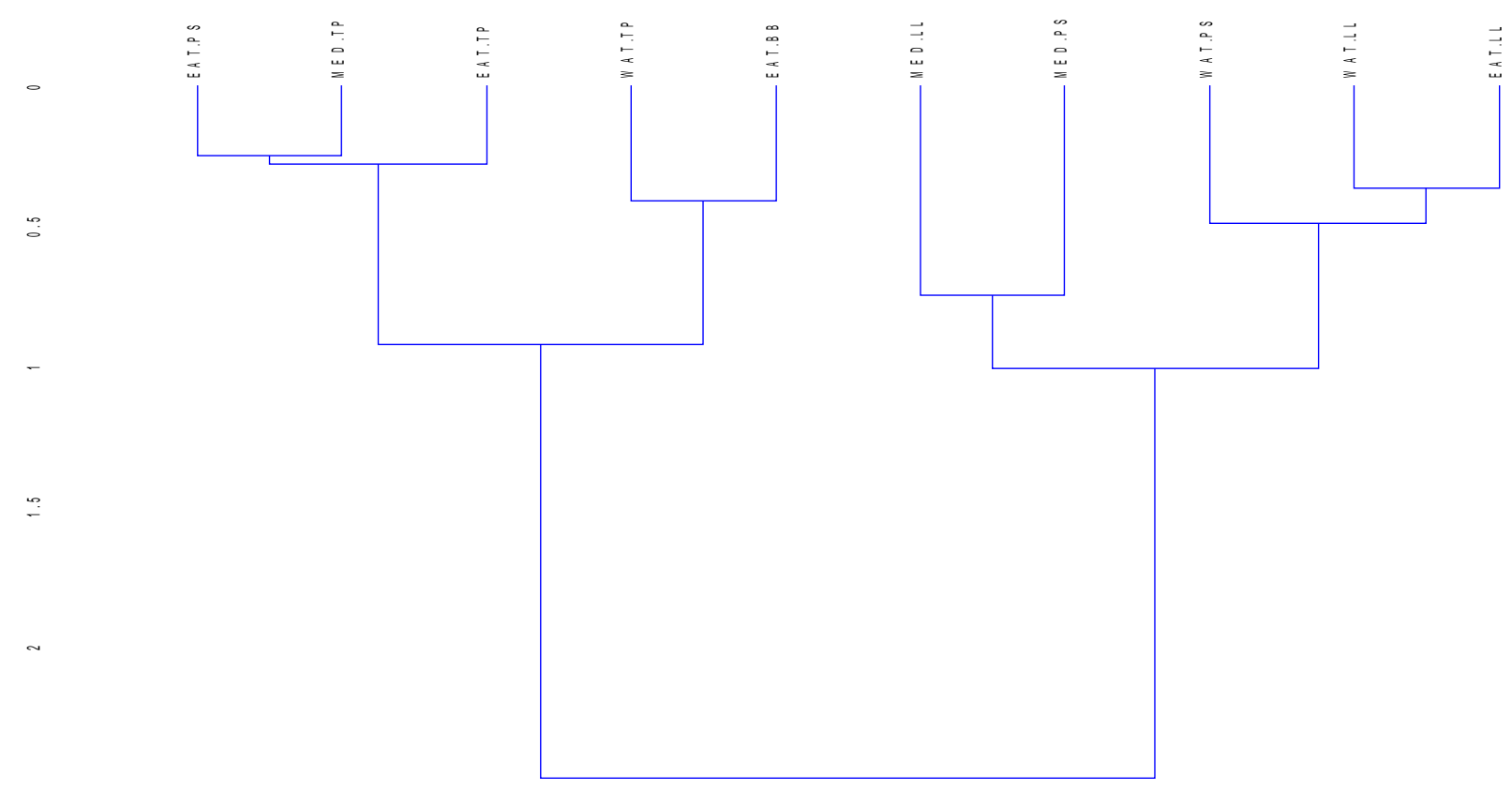




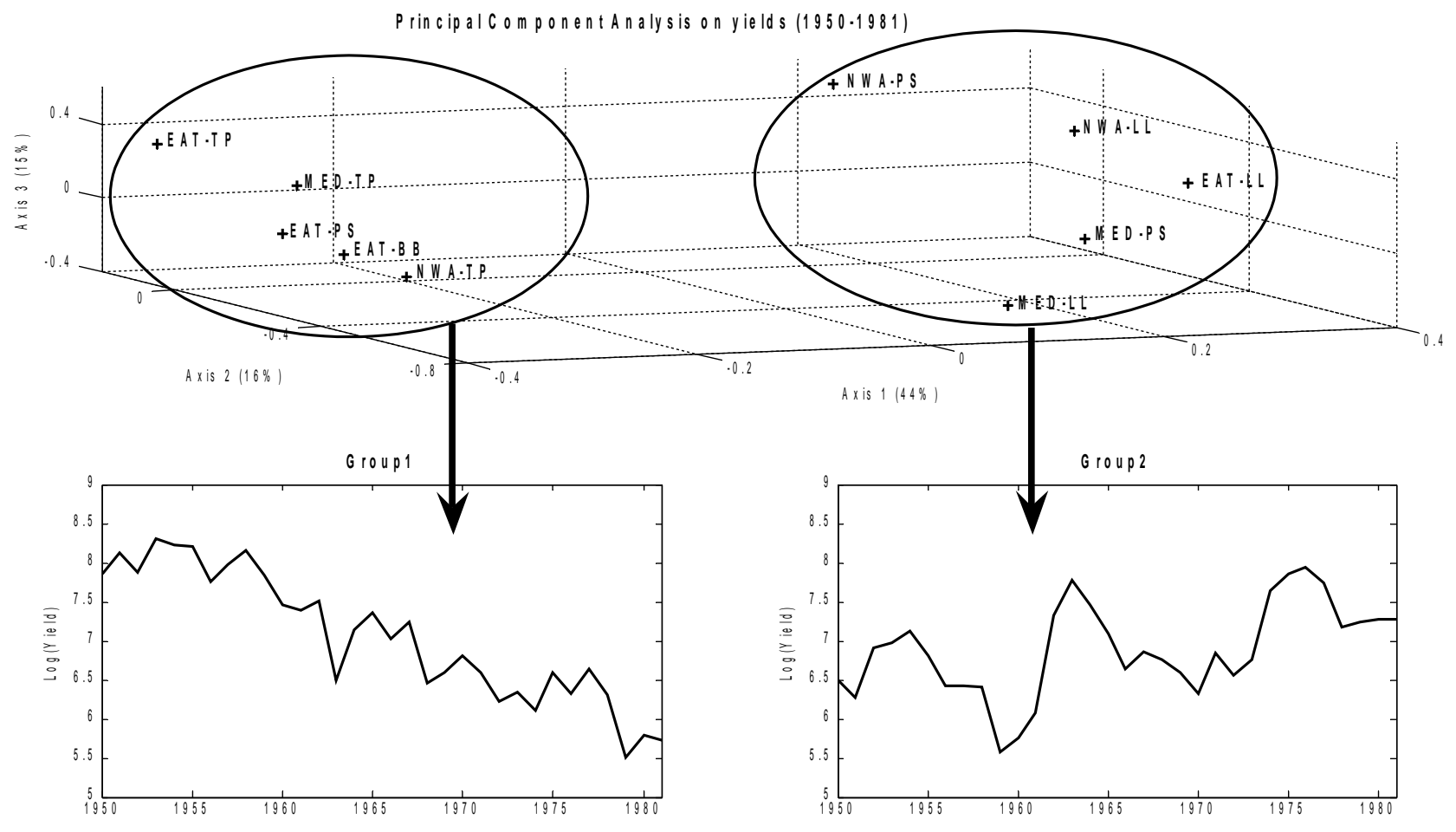




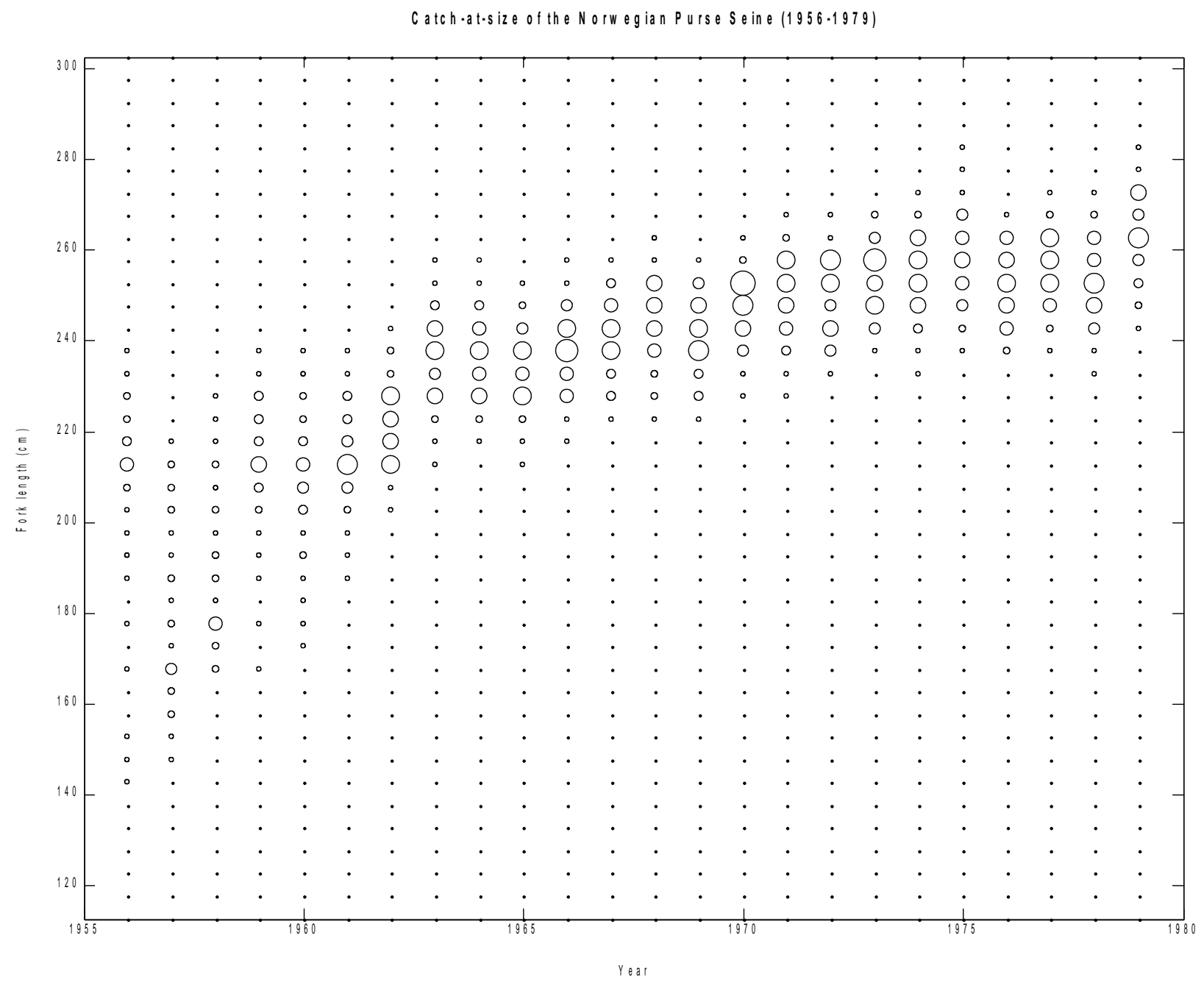



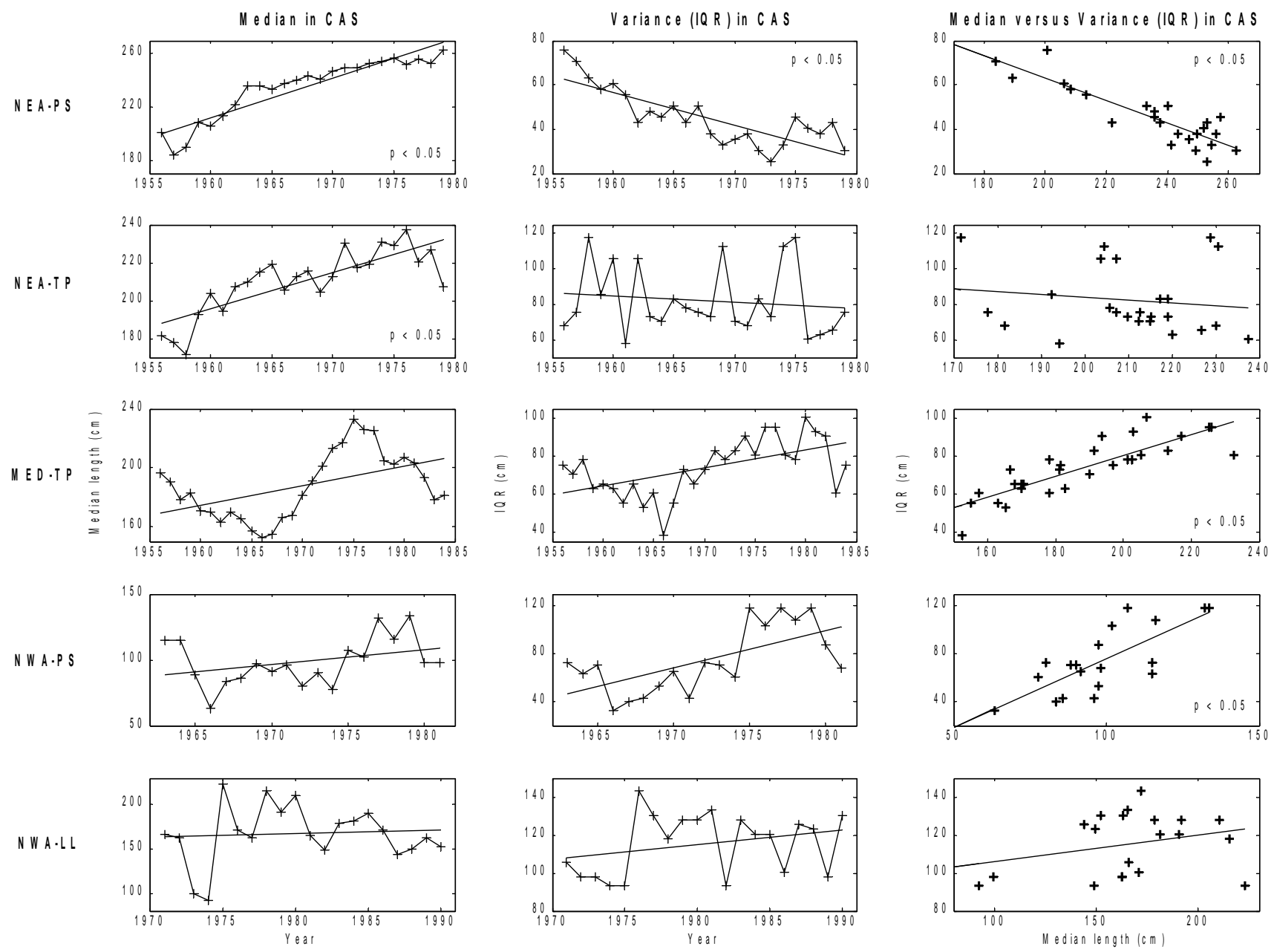

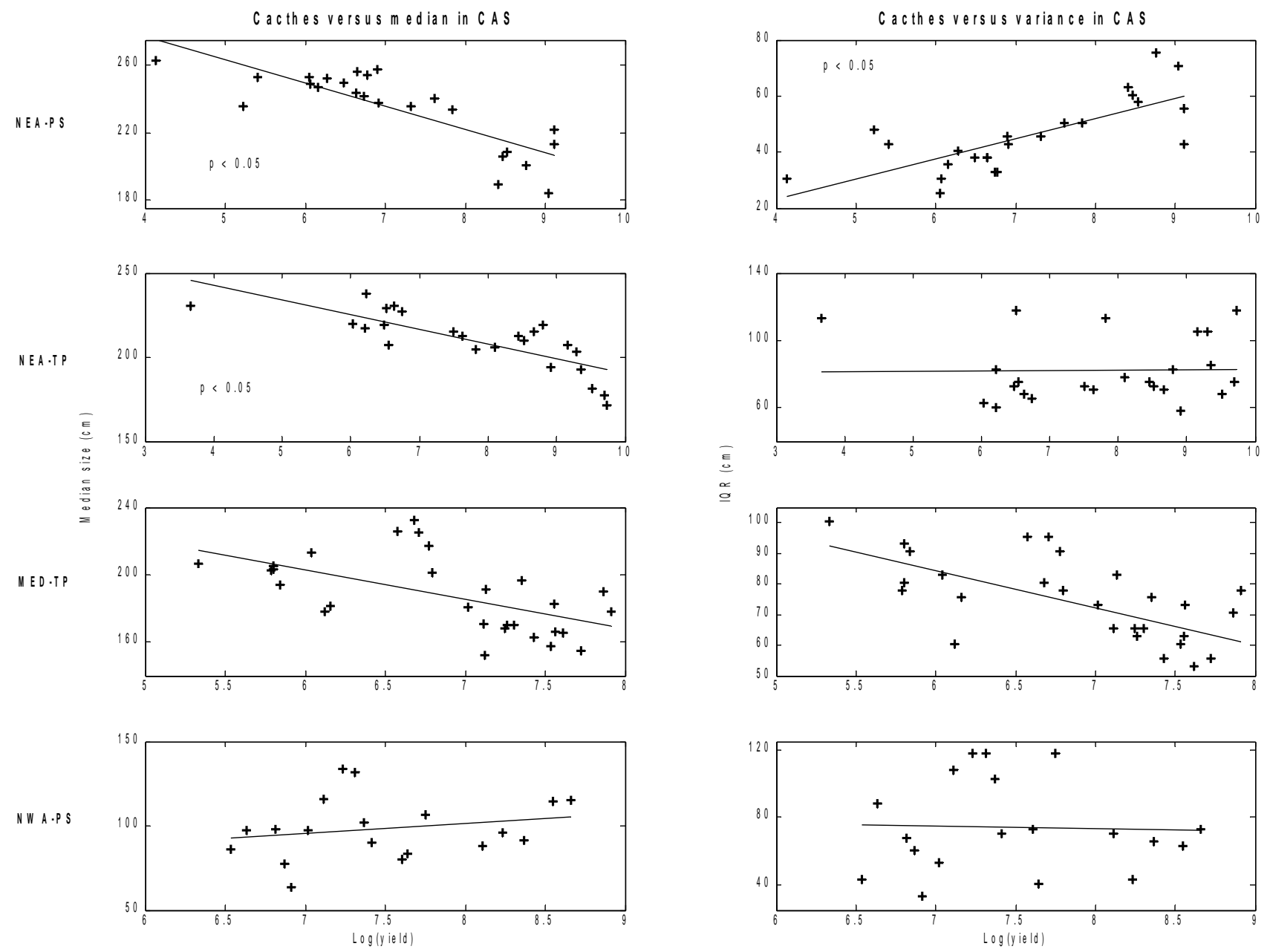

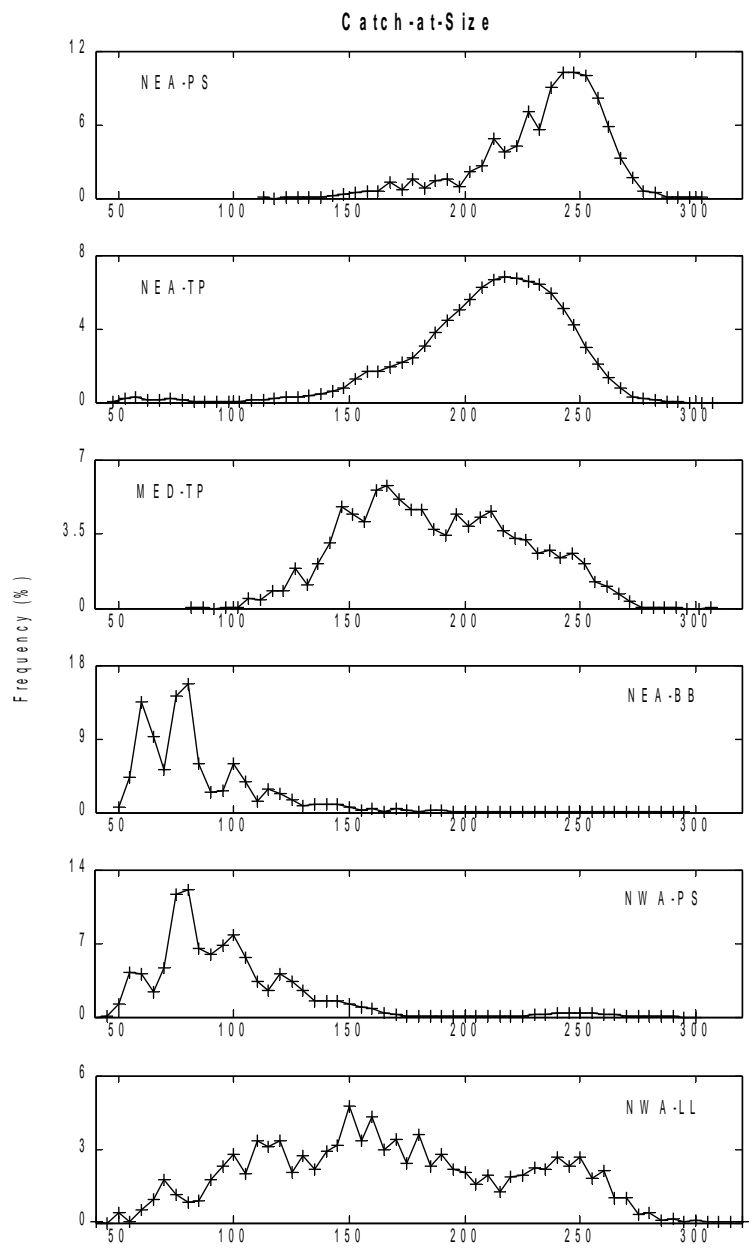

Fork Length $(\mathrm{cm}$ )
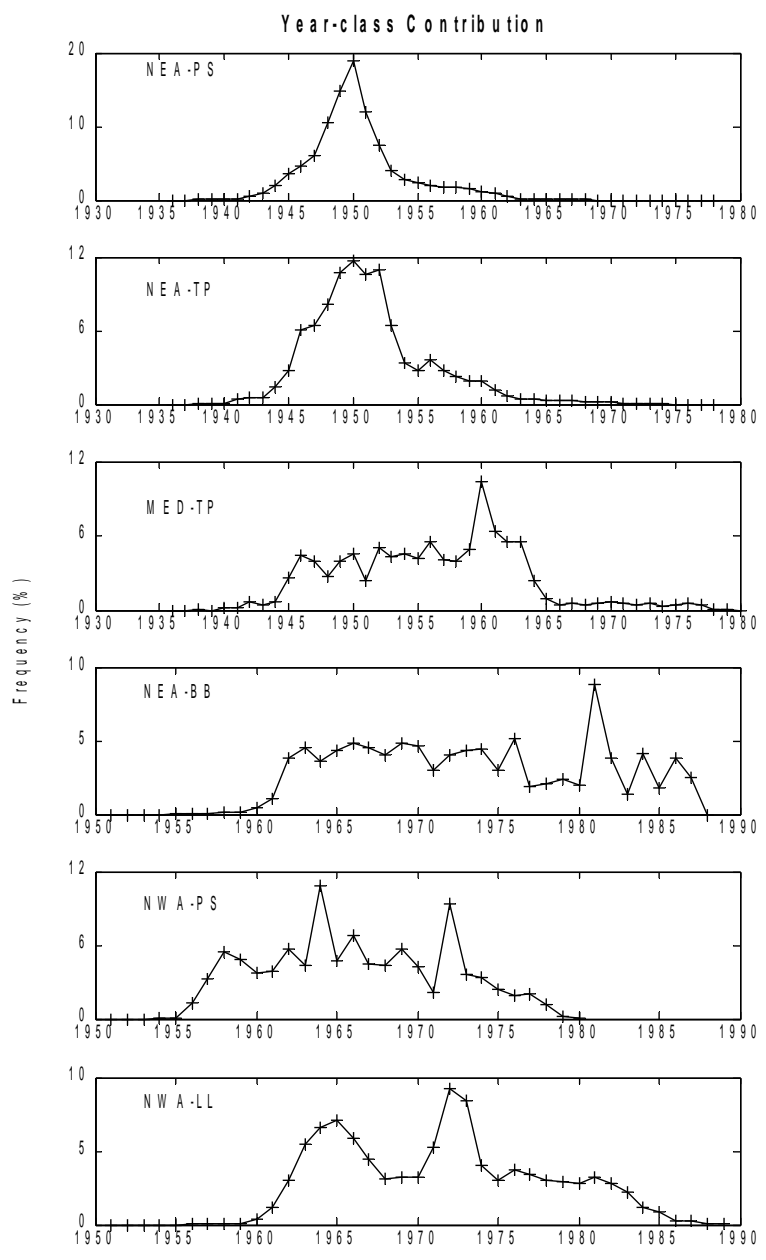

Year 

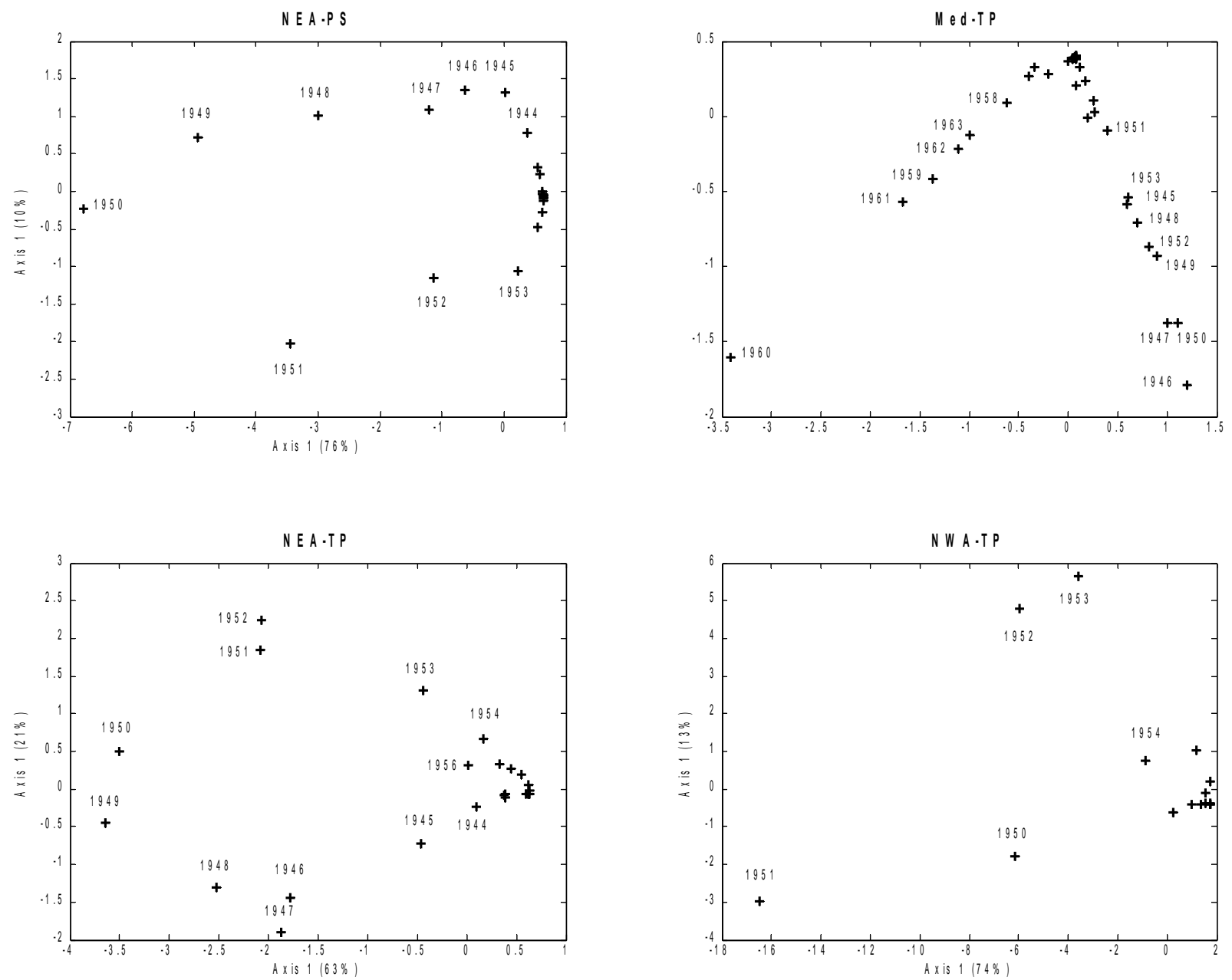


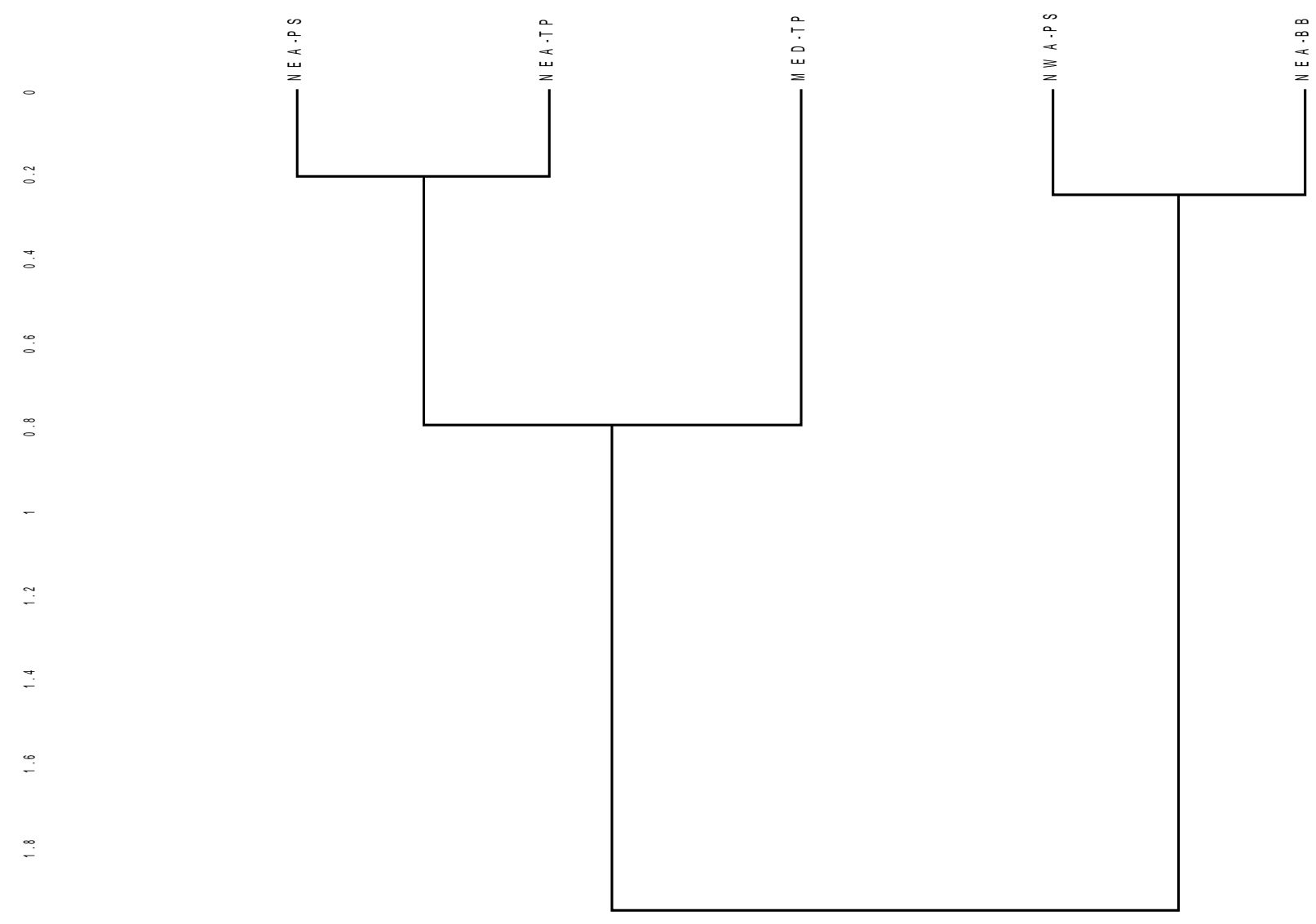

cluteron the 1966.1979 period 

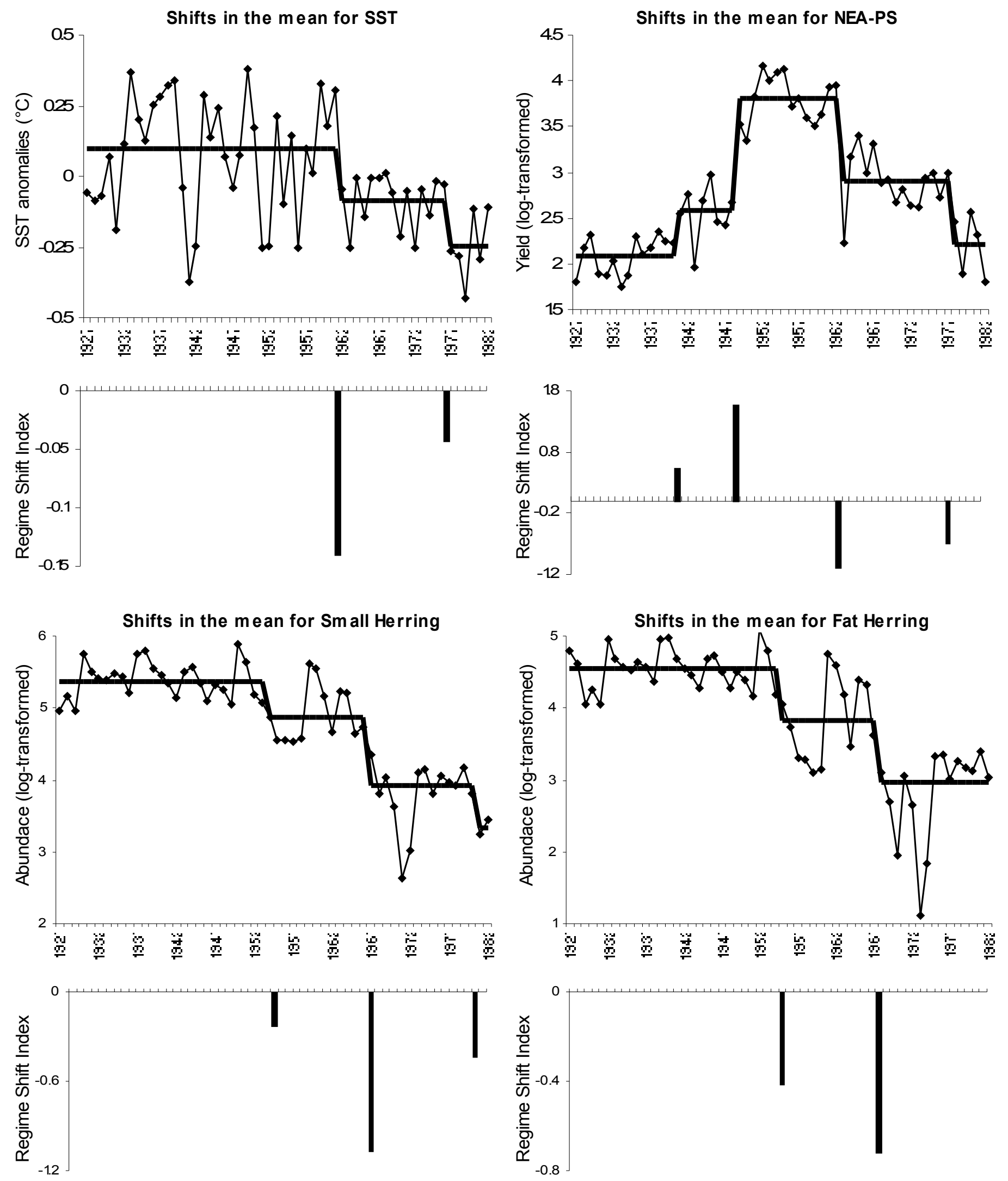


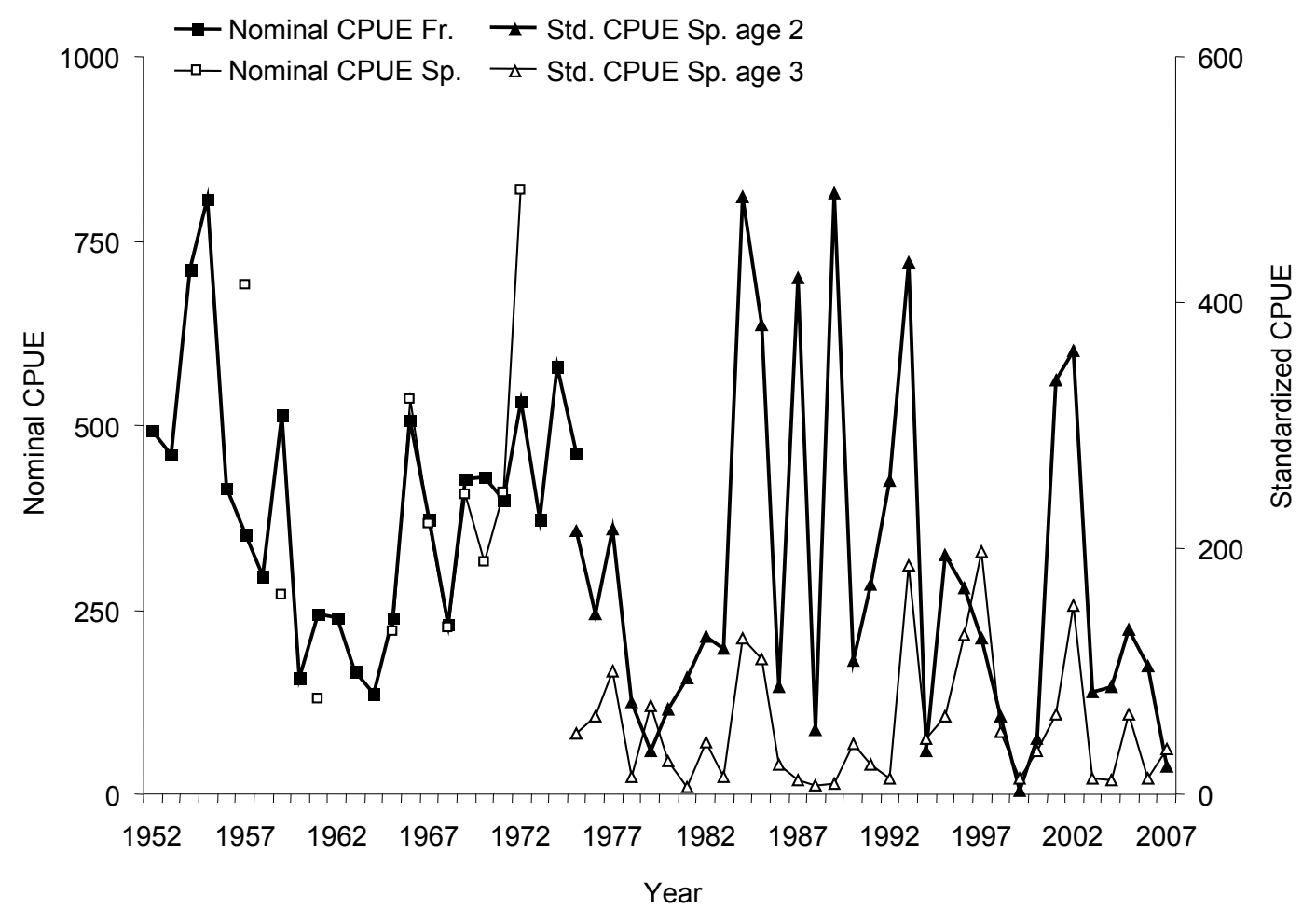

